\title{
Cymene-Osmium(II) Complexes with Amino-Phosphane Ligands as Precatalysts for Nitrile Hydration Reactions
}

\author{
Rebeca González-Fernández, ${ }^{[a]}$ Pascale Crochet, ${ }^{*[a]}$ and Victorio Cadierno ${ }^{*[a]}$
}

\begin{abstract}
Three different series of half-sandwich Os(II) complexes, namely $\left[\mathrm{OsCl}_{2}\left(\eta^{6}-p\right.\right.$-cymene $\left.)\left\{\mathrm{PPh}_{2}\left(\mathrm{NR}_{2}\right)\right\}\right][\mathrm{R}=\mathrm{Me}(\mathbf{5 a})$, Et (5b) $)$, $\left[\mathrm{OsCl}_{2}\left(\eta^{6}-p\right.\right.$-cymene $\left.)\left\{\mathrm{PPh}\left(\mathrm{NR}_{2}\right)_{2}\right\}\right][\mathrm{R}=\mathrm{Me}(\mathbf{6 a})$, Et $(\mathbf{6 b})]$ and $\left[\mathrm{OsCl}_{2}\left(\eta^{6}\right.\right.$-p-cymene $\left.)\left\{\mathrm{P}\left(\mathrm{NR}_{2}\right)_{3}\right\}\right][\mathrm{R}=\mathrm{Me}(\mathbf{7 a})$, Et $(\mathbf{7 b})]$, have been synthesized. These species proved to be catalytically active for the selective hydration of organonitriles, with compound $\left[\mathrm{OsCl}_{2}\left(\eta^{6}-p\right.\right.$ cymene) $\left.\left\{\mathrm{PPh}_{2}\left(\mathrm{NMe}_{2}\right)\right\}\right]$ (5a) being the most effective . In addition, the catalytic activity of $\mathbf{5 a}$ was found to be superior to those shown by related $\mathrm{Ru}(\mathrm{II}), \mathrm{Ru}(\mathrm{IV}), \mathrm{Rh}(\mathrm{I})$ and $\mathrm{Pt}(\mathrm{II})$ species containing the aminophosphane $\mathrm{PPh}_{2}\left(\mathrm{NMe}_{2}\right)$, i.e. compounds $\left[\mathrm{RuCl}_{2}\left(\eta^{6}-p\right.\right.$ cymene) $\left.\left\{\mathrm{PPh}_{2}\left(\mathrm{NMe}_{2}\right)\right\}\right]$ (10), $\left[\mathrm{RuCl}_{2}\left(\eta^{3}: \eta^{3}-\mathrm{C}_{10} \mathrm{H}_{16}\right)\left\{\mathrm{PPh}_{2}\left(\mathrm{NMe}_{2}\right)\right\}\right]$ (12), $\left[\mathrm{RhCl}(\mathrm{COD})\left\{\mathrm{PPh}_{2}\left(\mathrm{NMe}_{2}\right)\right\}\right]$ (13) and cis-[PtCl$\left.\left\{\mathrm{PPh}_{2}\left(\mathrm{NMe}_{2}\right)\right\}_{2}\right]$ (15). Details on the synthesis and characterization of complexes 10,12 and $\mathbf{1 5}$ are also included, along with a discussion on the role played by the ligand $\mathrm{PPh}_{2}\left(\mathrm{NMe}_{2}\right)$ during the catalytic reactions. In this sense, the amino-phosphane does not act as $\mathrm{H}$-bond acceptor for the water molecule, generating instead in the aqueous reaction medium the cooperative phosphinous acid ligand $\mathrm{PPh}_{2}(\mathrm{OH})$.
\end{abstract}

\section{Introduction}

Amide-bond forming reactions are key processes in organic chemistry because of the prevalence of this functionality in polymers, agrochemicals, natural products and pharmaceuticals. ${ }^{[1]}$ In this context, the hydration of nitriles is probably the simplest method to obtain primary amides in an atom-economical manner and, consequently, considerable efforts have been devoted in recent years to the development of transition-metal catalysts that enable such a transformation to occur surpassing the limitations usually encountered when traditional methodologies, based on the use of strong acids or bases (harsh reaction conditions, poor functional groups compatibility and over-hydrolysis of the desired amide products), are employed. ${ }^{[2]}$ As a result of the countless works carried out in the field, there is no doubt now that the appropriate selection of the auxiliary ligands bound to the metal is the key element to obtain homogeneous catalysts featuring high efficiency. Thus, a metal-ligand cooperative effect involving the simultaneous

[a] R. González-Fernández, Dr. P. Crochet, Dr. V. Cadierno Laboratorio de Compuestos Organometálicos y Catálisis (Unidad Asociada al CSIC), Centro de Innovación en Química Avanzada (ORFEO-CINQA), Departamento de Química Orgánica e Inorgánica, Instituto Universitario de Química Organometálica "Enrique Moles", Universidad de Oviedo, Julián Clavería 8, E-33006 Oviedo, Spain

E-mail: crochetpascale@uniovi.es (P.C.); vcm@uniovi.es (V.C.) Homepage: http://www.unioviedo.es/comorca activation of the nitrile (by coordination to the metal) and water molecules (through hydrogen-bonding interaction with a heteroatom present in the ligand backbone) has been very often proposed to explain the superior activities found with some catalysts, when compared with analogous systems containing "innocent" ligands non-functionalized with extra heteroatoms (Figure 1). ${ }^{[3]}$ Such an action mode has been evoked, for example, in the case of amino-phosphanes $\mathrm{PR}_{3-\mathrm{n}}\left(\mathrm{NR}_{2}^{\prime}\right)_{\mathrm{n}}(\mathrm{n}=1$ 3 ), ligands that have proven to be particularly useful in this catalytic transformation. ${ }^{[3 f, h, l, k, n, p, q]}$

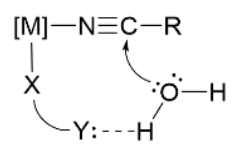

Figure 1. Cooperative effect via $\mathrm{H}$-bonding activation of the water molecule.

An alternative cooperative effect is that exerted by the closely related phosphinous acids $\mathrm{PR}_{2} \mathrm{OH}$, ligands that have also been extensively applied in the catalytic hydration of nitriles. ${ }^{[4]}$ As we recently evidenced through DFT calculations, in this case the reaction is facilitated by the initial formation of a five-membered ring metallacyclic intermediate, generated by intramolecular addition of the hydroxyl group of the ligand to the coordinated nitrile, which subsequently undergoes hydrolysis leading to the final primary amide product (see Scheme 1). ${ }^{[5]}$

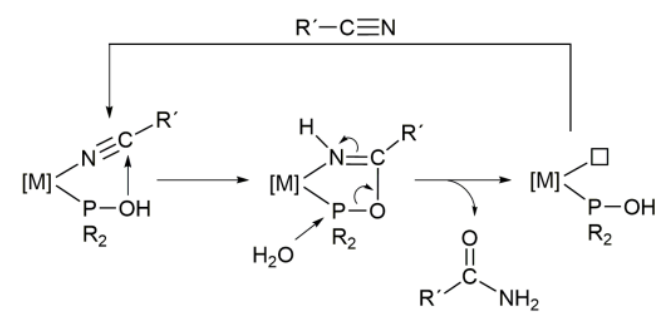

Scheme 1. The cooperative effect of phophinous acids in the catalytic hydration of nitriles.

In the context of these studies with phosphinous acids, we were also surprised to find that the osmium(II) complex $\left[\mathrm{OsCl}_{2}\left(\eta^{6}\right.\right.$-p-cymene) $\left.\left(\mathrm{PMe}_{2} \mathrm{OH}\right)\right]$ exhibits a catalytic performance similar (or even superior in the case of the less reactive aliphatic nitriles) to its ruthenium counterpart $\left[\mathrm{RuCl}_{2}\left(\eta^{6}-p\right.\right.$ cymene) $\left.\left(\mathrm{PMe}_{2} \mathrm{OH}\right)\right]^{\left[{ }^{[b, 6]} \text { We }\right.}$ must stress here that the slow ligand exchange kinetics in Os complexes has been for long time considered as a major drawback for the application of osmium derivatives in homogeneous catalysis. ${ }^{[7]} \mathrm{A}$ clear example of the underestimation of the catalytic potential of this metal is the fact that, contrary to the case of ruthenium, ${ }^{[6]}$ to date 
the number of studies on nitriles hydration using osmium compounds can be counted on the fingers of one hand. ${ }^{[5 b, 8]}$ The remarkable catalytic activity featured by $\left[\mathrm{OsCl}_{2}\left(\eta^{6}-p\right.\right.$ cymene)( $\left.\left(\mathrm{PMe}_{2} \mathrm{OH}\right)\right]$ supports the exploration of new osmium complexes with cooperative ligands as potential catalysts for nitrile hydration reactions. That is why we decided to evaluate the behavior of a series of mononuclear Os(II) derivatives containing the readily available amino-phosphanes $\mathrm{PPh}_{3-\mathrm{n}}\left(\mathrm{NR}_{2}\right)_{\mathrm{n}}$ $(\mathrm{R}=\mathrm{Me}, \mathrm{Et} ; \mathrm{n}=1-3) \cdot{ }^{\left[{ }^{[9]}\right.}$ Results from this study are presented herein. ${ }^{[10]}$

\section{Results and Discussion}

Our research began with the preparation of a family of halfsandwich Os(II) complexes of general composition $\left[\mathrm{OsCl}_{2}\left(\eta^{6}-p\right.\right.$ cymene) $\left.\left\{\mathrm{PPh}_{3-\mathrm{n}}\left(\mathrm{NR}_{2}\right)_{\mathrm{n}}\right\}\right](\mathbf{5 - 7 a , b})$, through the treatment of the dimeric precursor $\left[\left\{\mathrm{OsCl}(\mu-\mathrm{Cl})\left(\eta^{6}-p \text {-cymene }\right)\right\}_{2}\right]$ (1) with two equivalents of the monoamino $\mathrm{PPh}_{2}\left(\mathrm{NR}_{2}\right)[R=\mathrm{Me}(\mathbf{2 a})$, Et $(\mathbf{2 b})]$, diamino $\mathrm{PPh}\left(\mathrm{NR}_{2}\right)_{2}[\mathrm{R}=\mathrm{Me}(\mathbf{3 a})$, Et $(\mathbf{3} \mathbf{b})]$ and trisaminophosphanes $\mathrm{P}\left(\mathrm{NR}_{2}\right)_{3}[\mathrm{R}=\mathrm{Me}(\mathbf{4 a})$, Et $(\mathbf{4} \mathbf{b})]$. As shown in Scheme 2, the chloride bridges-splitting reactions of dimer 1 with 2-4a,b proceeded rapidly and cleanly in dichloromethane under ambient conditions, affording the mononuclear derivatives 5$7 \mathbf{a}, \mathbf{b}$ in high yields (76-88\%).

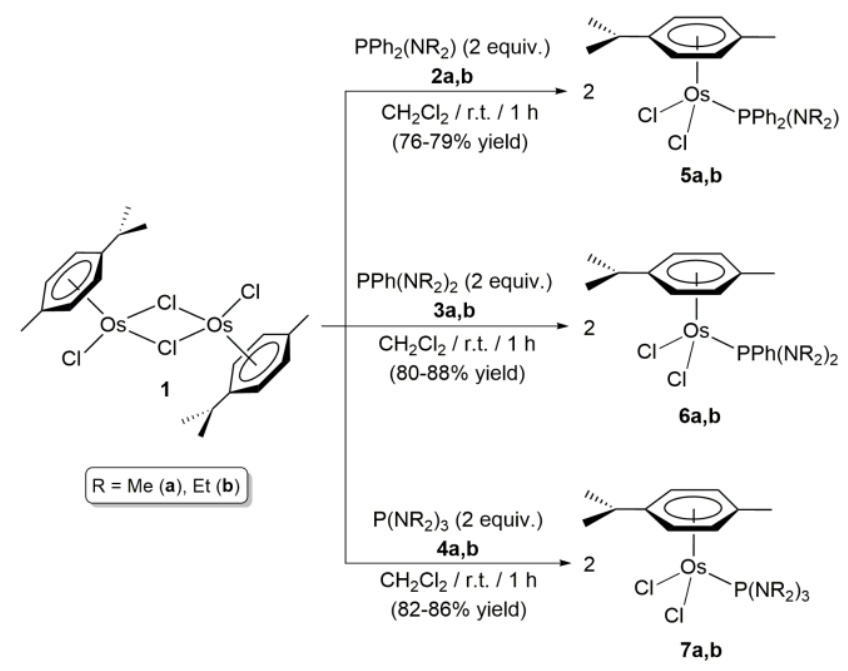

Scheme 2. Synthesis of the amino-phosphane-Os(II) complexes 5-7a,b.

Complexes $\mathbf{5 - 7 a , b}$, isolated as air-stable orange solids, are soluble in polar solvents, such as dichloromethane, chloroform, THF and alcohols, partially soluble in diethyl ether, and insoluble in $n$-alkanes. They are also partially soluble in water, with the solubility in this medium increasing with the number of amino groups present in the phosphane ligand. The characterization of 5-7a,b was straightforward following the analytical and spectroscopic data obtained (details are given in the Supporting Information). In particular, the ${ }^{31} \mathrm{P}\left\{{ }^{1} \mathrm{H}\right\}$ NMR spectra confirmed the coordination of $\mathrm{PPh}_{3-\mathrm{n}}\left(\mathrm{NR}_{2}\right)_{\mathrm{n}}$ ligands to the osmium center by the appearance of singlet resonances shielded 30-40 ppm with respect to those of the uncoordinated phosphanes (see Table 1). The ${ }^{1} \mathrm{H}$ and ${ }^{13} \mathrm{C}\left\{{ }^{1} \mathrm{H}\right\}$ NMR spectra were also fully consistent with the proposed formulations, showing the expected signals for the $\eta^{6}$-coordinated $p$-cymene unit, and the aromatic and alkylic groups of the amino-phosphanes. For the former, only two signals for the aromatic $\mathrm{CH}$ protons and carbon atoms of the cymene ring were observed, which is in full accord with the presence of a symmetry plane in complexes $\mathbf{5 - 7 a , b}$.

Table 1. ${ }^{31} \mathrm{P}\left\{{ }^{1} \mathrm{H}\right\}$ NMR data for the amino-phosphanes 2-4a,b and their respective ( $\eta^{6}$-p-cymene)-Os(II) complexes 5-7a,b. b. ${ }^{[a]}$

\begin{tabular}{llll}
\hline Amino-phosphane & $\delta \mathrm{p}^{[\mathrm{b}]}$ & Os(II) complex & $\delta_{\mathrm{p}}^{[\mathrm{c}]}$ \\
\hline $\mathrm{PPh}_{2}\left(\mathrm{NMe}_{2}\right)(\mathbf{2 a})$ & 65.7 & $\mathbf{5 a}$ & 30.0 \\
$\mathrm{PPh}_{2}\left(\mathrm{NEt}_{2}\right)(\mathbf{2 b})$ & 63.0 & $\mathbf{5 b}$ & 32.6 \\
$\mathrm{PPh}\left(\mathrm{NMe}_{2}\right)_{2}(\mathbf{3 a})$ & 101.2 & $\mathbf{6 a}$ & 51.3 \\
$\mathrm{PPh}\left(\mathrm{NEt}_{2}\right)_{2}(\mathbf{3 b})$ & 99.1 & $\mathbf{6 b}$ & 51.0 \\
$\mathrm{P}\left(\mathrm{NMe}_{2}\right)_{3}(\mathbf{4 a})$ & 122.7 & $\mathbf{7 a}$ & 68.0 \\
$\mathrm{P}\left(\mathrm{NEt}_{2}\right)_{3}$ (4b) & 118.8 & $\mathbf{7 b}$ & 65.7 \\
\hline
\end{tabular}

[a] Chemical shift values are given in ppm. [b] Spectra were recorded in $\mathrm{CDCl}_{3}$ at $25^{\circ} \mathrm{C}$. [c] Spectra were recorded in $\mathrm{CD}_{2} \mathrm{Cl}_{2}$ at $25^{\circ} \mathrm{C}$.

The catalytic potential of the Os(II) derivatives 5-7a,b for nitrile hydration reactions was subsequently explored using benzonitrile as model substrate. In a typical experiment, the corresponding complex ( $5 \mathrm{~mol} \%$ of Os) was added under inert atmosphere to a $0.33 \mathrm{M}$ aqueous solution of benzonitrile, and the resulting mixture heated in an oil bath at $100{ }^{\circ} \mathrm{C}$. For comparative purposes, the behavior of the dimeric precursor $\left[\left\{\mathrm{OsCl}(\mu \text {-Cl })\left(\eta^{6}-p \text {-cymene }\right)\right\}_{2}\right]$ (1) and the structurally related mononuclear Os(II) complex [OsCl $2\left(\eta^{6}\right.$-p-cymene $\left.)\left(\mathrm{PPh}_{3}\right)\right](\mathbf{8})^{[11]}$ was also investigated under identical conditions. The results obtained are collected in Table 2. Thus, as shown in entries 1 and 2, the catalytic activities of dimer $\mathbf{1}$ and the triphenylphosphane complex 8 were very low, leading to the desired benzamide in only $7-10 \%$ GC yield after 24 hours of heating. In marked contrast, the amino-phosphane derivatives 5$7 \mathbf{a}, \mathbf{b}$ proved to be much more active, generating the benzamide product in almost quantitative GC yield (97-98\%) after 1 (complexes 5-6a,b; entries 3-6) or $5 \mathrm{~h}$ (complexes $\mathbf{7 a , b}$; entries 7-8). These results clearly demonstrate the beneficial effect of the inclusion of the $\mathrm{H}$-bonding-donor amino groups in the skeleton of the auxiliary phosphane ligand. Further experiments conducted with $\left[\mathrm{OsCl}_{2}\left(\eta^{6}\right.\right.$-p-cymene) $\left.\left\{\mathrm{PPh}_{2}\left(\mathrm{NR}_{2}\right)\right\}\right][\mathrm{R}=\mathrm{Me}(\mathbf{5 a})$, Et (5b); entries 9-10] and [OsCl ${ }_{2}\left(\eta^{6}-p\right.$-cymene $\left.)\left\{\mathrm{PPh}\left(\mathrm{NR}_{2}\right)_{2}\right\}\right][\mathrm{R}=$ Me (6a), Et (6b); entries 11-12] at a lower metal loading (2 mol\%) allowed us to identify [OsCl $2\left(\eta^{6}\right.$-p-cymene $\left.)\left\{\mathrm{PPh}_{2}\left(\mathrm{NMe}_{2}\right)\right\}\right]$ (5a) as the most active complex of the series. Under these conditions, it was able to generate benzamide in $97 \%$ GC yield after $1 \mathrm{~h}$ (entry 9 ). Remarkably, reduction of the loading of $\mathbf{5 a}$ to 1 mol\% still produced benzamide in $97 \%$ yield without a drastic increase in the reaction time $\left(3 \mathrm{~h}\right.$; TOF $=32 \mathrm{~h}^{-1}$; entry 13). High 
conversions were also achieved by performing the hydration reaction with only $0.5 \mathrm{~mol} \%$ of $5 \mathbf{a}$, or with $1 \mathrm{~mol} \%$ of $5 \mathbf{a}$ at $80{ }^{\circ} \mathrm{C}$, but in both cases a much longer reaction time $(24 \mathrm{~h})$ was required (entries 14 and 15, respectively). At this point we would like to stress that $(I)$ in no case traces of benzoic acid were detected by GC in the crude reaction mixtures, (ii) no organic cosolvents were required, and (iii) the reactions proceeded cleanly in the absence of basic or acidic additives.

Table 2. Hydration of benzonitrile into benzamide catalyzed by different metal complexes in water. ${ }^{[a]}$

$$
\mathrm{Ph}-\mathrm{C} \equiv \mathrm{N} \stackrel{[\mathrm{M}](0.5-5 \mathrm{~mol} \%)}{\mathrm{H}_{2} \mathrm{O} / 100^{\circ} \mathrm{C}}
$$

\begin{tabular}{|c|c|c|c|c|}
\hline Entry & Catalyst & $\mathrm{Mol} \%$ of $\mathrm{M}$ & $t[\mathrm{~h}]$ & Yield $[\%]^{[b]}$ \\
\hline 1 & 1 & 5 & $1(24)$ & $<1(7)$ \\
\hline 2 & 8 & 5 & $1(24)$ & $<1(10)$ \\
\hline 3 & $5 a$ & 5 & 1 & 98 \\
\hline 4 & $5 b$ & 5 & 1 & 98 \\
\hline 5 & $6 a$ & 5 & 1 & 98 \\
\hline 6 & $6 b$ & 5 & 1 & 98 \\
\hline 7 & $7 a$ & 5 & $1(5)$ & 77 (97) \\
\hline 8 & $7 b$ & 5 & $1(5)$ & $51(98)$ \\
\hline 9 & $5 a$ & 2 & 1 & 97 \\
\hline 10 & $5 b$ & 2 & 1 & 88 \\
\hline 11 & $6 a$ & 2 & 1 & 91 \\
\hline 12 & $6 b$ & 2 & 1 & 89 \\
\hline 13 & $5 a$ & 1 & $1(3)$ & 37 (97) \\
\hline 14 & $5 a$ & 0.5 & $1(24)$ & $24(96)$ \\
\hline $15^{[c]}$ & $5 a$ & 1 & $1(24)$ & $12(99)$ \\
\hline 16 & 10 & 1 & $1(3)$ & $34(82)$ \\
\hline 17 & 12 & 1 & $1(3)$ & $11(74)$ \\
\hline 18 & 13 & 1 & $1(3)$ & $0(1)$ \\
\hline 19 & 15 & 1 & $1(3)$ & $1(3)$ \\
\hline
\end{tabular}

[a] Reactions performed under argon atmosphere at $100 \stackrel{\circ}{\mathrm{C}}$ using $1 \mathrm{mmol}$ of benzonitrile ( $0.33 \mathrm{M}$ in water). [b] Yield of benzamide determined by $\mathrm{GC}$ (uncorrected GC areas). [c] Reaction performed at $80 \stackrel{\circ}{\circ}$.

In order to better determine the utility of osmium in this catalytic transformation, we next conducted a comparative study of the activity of $\left[\mathrm{OsCl}_{2}\left(\eta^{6}\right.\right.$-p-cymene $\left.)\left\{\mathrm{PPh}_{2}\left(\mathrm{NMe}_{2}\right)\right\}\right]$ (5a) with that of related ruthenium, rhodium and platinum complexes containing the amino-phosphane ligand $\mathrm{PPh}_{2}\left(\mathrm{NMe}_{2}\right)(\mathbf{2 a})$. These particular metals were chosen as they are among the most commonly employed for the catalytic hydration of nitriles. ${ }^{[6,12,13]}$
Concerning ruthenium, we decided to synthesize the $\mathrm{Ru}(\mathrm{II})$ complex $\left[\mathrm{RuCl}_{2}\left(\eta^{6}\right.\right.$-p-cymene $\left.)\left\{\mathrm{PPh}_{2}\left(\mathrm{NMe}_{2}\right)\right\}\right]$ (10), structurally analogous to $\mathbf{5 a}$, and the bis(allyl)-ruthenium(IV) derivative $\left[\mathrm{RuCl}_{2}\left(\eta^{3}: \eta^{3}-\mathrm{C}_{10} \mathrm{H}_{16}\right)\left\{\mathrm{PPh}_{2}\left(\mathrm{NMe}_{2}\right)\right\}\right] \quad\left(12 ; \quad \mathrm{C}_{10} \mathrm{H}_{16}=2,7-\right.$ dimethylocta-2,6-diene-1,8-diyl). ${ }^{[14]}$ As shown in Scheme 3 , these compounds could be obtained in high yield $(80-89 \%)$ by reacting the appropriate dimeric precursor, i.e. $\left[\left\{\mathrm{RuCl}(\mu-\mathrm{Cl})\left(\eta^{6}-p\right.\right.\right.$ cymene) $\left.\}_{2}\right]$ (9) and $\left[\left\{\mathrm{RuCl}(\mu-\mathrm{Cl})\left(\eta^{3}: \eta^{3}-\mathrm{C}_{10} \mathrm{H}_{16}\right)\right\}_{2}\right]$ (11), respectively, with two equivalents of $\mathrm{PPh}_{2}\left(\mathrm{NMe}_{2}\right)$ (2a) in dichloromethane at room temperature.

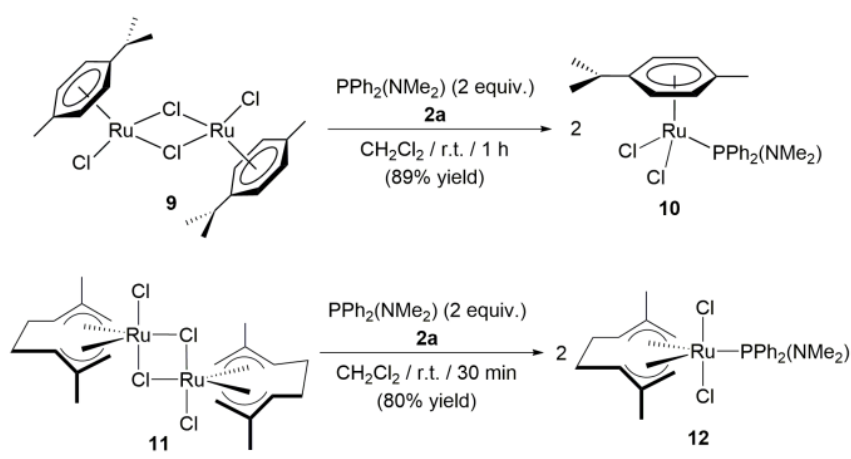

Scheme 3. Synthesis of the $R u(I I)$ and $R u(I V)$ complexes 10 and 12.

The characterization of the novel complexes $\mathbf{1 0}$ and $\mathbf{1 2}$ was achieved by elemental analyses and multinuclear NMR spectroscopy (see the Supporting Information for details). Worthy of note is the fact that the coordination of the ligand $\mathrm{PPh}_{2}\left(\mathrm{NMe}_{2}\right)$ (2a) to the $\mathrm{Ru}(\mathrm{II})$ and $\mathrm{Ru}(\mathrm{IV})$ fragments was reflected in the ${ }^{31} \mathrm{P}\left\{{ }^{1} \mathrm{H}\right\}$ NMR spectra by a downfield shift of the phosphorous resonance [from $65.7(2 \mathrm{a})$ to $71.2(\mathbf{1 0})$ and 82.3 (12)]. As previously mentioned, the opposite situation was found in the case of the $\mathrm{Os}(\mathrm{II})$ derivative $\left[\mathrm{OsCl}_{2}\left(\eta^{6}-p\right.\right.$ cymene $\left.)\left\{\mathrm{PPh}_{2}\left(\mathrm{NMe}_{2}\right)\right\}\right] \quad(\mathbf{5 a} ; \quad \delta \mathrm{p}=30.0 \mathrm{ppm})$, the different behavior observed being attributed to the "paramagnetic shielding" effect of osmium. ${ }^{[15]}$ On the other hand, the ${ }^{1} \mathrm{H}$ and ${ }^{13} \mathrm{C}\left\{{ }^{1} \mathrm{H}\right\}$ NMR spectra of complex 12 showed a single set of signals for the two allylic moieties of the $\mathrm{C}_{10} \mathrm{H}_{16}$ ligand, indicating that the two halves of the 2,7-dimethylocta-2,6-diene-1,8-diyl skeleton are in equivalent environments. This characteristic pattern confirms the coordination of the phosphane in the equatorial position of the trigonal bipyramidal ruthenium(IV) center. ${ }^{[16]}$

Once characterized, the ruthenium derivatives 10 and 12 were checked as catalysts in the hydration of the model benzonitrile, performing the reactions in pure water, at $100 \stackrel{\circ}{\circ}$, and with a metal loading of $1 \mathrm{~mol} \%$. As shown in entries 16 and 17 (Table 2), both complexes were active in the process delivering benzamide in 82 and $74 \%$ GC yield, respectively, after $3 \mathrm{~h}$, values that are clearly lower to that obtained with $\left[\mathrm{OsCl}_{2}\left(\eta^{6}\right.\right.$ p-cymene) $\left.\left\{\mathrm{PPh}_{2}\left(\mathrm{NMe}_{2}\right)\right\}\right]$ (5a) under identical experimental conditions ( $97 \%$ GC yield; entry 13). Further evidences of the superior reactivity of 5 a were gained when the known $\mathrm{Rh}(\mathrm{I})$ $\left[\mathrm{RhCl}(\mathrm{COD})\left\{\mathrm{PPh}_{2}\left(\mathrm{NMe}_{2}\right)\right\}\right] \quad(\mathbf{1 3} ; \mathrm{COD}=1,5 \text {-cyclooctadiene })^{[3 \mathrm{q}]}$ and the novel $\mathrm{Pt}(\mathrm{II})$ cis-[ $\left[\mathrm{PtCl}_{2}\left\{\mathrm{PPh}_{2}\left(\mathrm{NMe}_{2}\right)\right\}_{2}\right]$ (15) complexes 
(see Figure 2) were employed as catalysts (1 mol\%), since in these cases only $1-3 \%$ of benzamide was formed after $3 \mathrm{~h}$ of heating at $100{ }^{\circ} \mathrm{C}$ (entries 18 and 19 in Table 2). ${ }^{[17]}$ Concerning the synthesis of cis-[ $\left.\mathrm{PtCl}_{2}\left\{\mathrm{PPh}_{2}\left(\mathrm{NMe}_{2}\right)\right\}_{2}\right](15)$, it was isolated in $75 \%$ yield from the reaction of 1,5-cyclooctadiene- $\mathrm{Pt}$ (II) precursor $\left[\mathrm{PtCl}_{2}(\mathrm{COD})\right]$ (14) with two equivalents of the aminophosphane 2a (details are given in the Supporting Information). In its ${ }^{31} \mathrm{P}\left\{{ }^{1} \mathrm{H}\right\}$ NMR spectrum, a singlet resonance shielded with respect to that of free ligand $2 \mathbf{a}(\delta \mathrm{p}=52.9 \mathrm{vs} 65.7 \mathrm{ppm})$, and featuring the expected ${ }^{195} \mathrm{Pt}$ satellites, was present, thus demonstrating that only one of the two potential geometric isomers was formed. The large ${ }^{1} \mathrm{JPt}_{\mathrm{P}, \mathrm{P}}$ coupling constant observed (3979 Hz), characteristic of $\mathrm{Pt}(\mathrm{II})$ complexes containing two phosphane ligands mutually cis disposed, ${ }^{[18]}$ was decisive to elucidate the stereochemistry of $15 .^{[19]}$

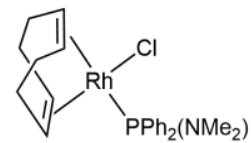

13

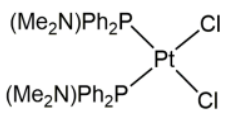

15
Figure 2. Structures of the $\mathrm{Rh}(\mathrm{I})$ and $\mathrm{Pt}(\mathrm{II})$ complexes $\mathbf{1 3}$ and $\mathbf{1 5 .}$

The next step of our study focused on the evaluation of the scope of complex $\left[\mathrm{OsCl}_{2}\left(\eta^{6}\right.\right.$-p-cymene $\left.)\left\{\mathrm{PPh}_{2}\left(\mathrm{NMe}_{2}\right)\right\}\right]$ (5a). To this end, a variety of organonitriles were subjected to the action of this compound $(1 \mathrm{~mol} \%)$ in pure water $(0.33 \mathrm{M}$ solutions) at $100{ }^{\circ} \mathrm{C}$. The results obtained are summarized in Table 3 . Thus, as observed for benzonitrile (entry 1 ), other aromatic nitriles could be transformed into the corresponding benzamides in high yields ( $\geq 93 \% \mathrm{GC}$ yield) regardless of their substitution pattern or electronic nature (entries 2-14). However, we must note that a slight influence of the electronic properties of the aryl rings on the rate of the hydration process was observed, with those substrates containing electron-donating groups showing a lower reactivity (entries 11-14 vs 2-10). In the particular case of 4aminobenzonitrile a extremely long reaction time $(24 \mathrm{~h})$ was needed to generate the corresponding benzamide in high yield (entry 14), suggesting that the amino group probably competes with the cyano one for coordination to the metal fragment. Complex $\mathbf{5 a}$ was also effective in hydrating heteroaromatic nitriles (entries 15-17), observing again for pyrrole-2-carbonitrile a drastic reduction of the reaction rate compared to related systems containing furyl or thienyl units (entry 17 vs 15-16). It seems therefore that the presence of potentially coordinating nitrogenated functionalities on the substrate skeleton has a detrimental effect on the catalytic reaction, although not enough to completely suppress the activity of $\mathbf{5 a}$.

As shown in entries 18-25, aliphatic nitriles, including synthetically relevant $\beta$-ketonitriles (entries 24-25), ${ }^{[20]}$ were also tolerated and could be converted into the respective amides in high yields and short times, thus fully demonstrating the wide scope of the process. Worthy of note is the fact that, in most cases, isolation of the final amide product could be easily achieved by simple crystallization upon cooling of the reaction mixture in an ice bath. ${ }^{[21]}$
Table 3. Catalytic hydration of nitriles in water using complex $\left[\mathrm{OsCl}_{2}\left(\eta^{6}-p\right.\right.$ cymene) $\left.\left\{\mathrm{PPh}_{2}\left(\mathrm{NMe}_{2}\right)\right\}\right](\mathbf{5 a})$ : Scope of the process. ${ }^{[\mathrm{a}]}$

$$
\mathrm{R}-\mathrm{C} \equiv \mathrm{N} \stackrel{\mathbf{5 a}(1 \mathrm{~mol} \%)}{\mathrm{H}_{2} \mathrm{O} / 100^{\circ} \mathrm{C}} \underset{\mathrm{R}}{\stackrel{\mathrm{O}}{\mathrm{NH}_{2}}}
$$

\begin{tabular}{|c|c|c|c|c|}
\hline Entry & Substrate & $t[\mathrm{~h}]$ & Yield $[\%]^{[b]}$ & TOF $\left[\mathrm{h}^{-1}\right]^{[c]}$ \\
\hline 1 & $\mathrm{R}=\mathrm{Ph}$ & 3 & $97(90)$ & 32 \\
\hline 2 & $\mathrm{R}=\mathrm{C}_{6} \mathrm{~F}_{5}$ & 0.5 & $>99(93)$ & 200 \\
\hline 3 & $\mathrm{R}=2-\mathrm{C}_{6} \mathrm{H}_{4} \mathrm{~F}$ & 2 & $98(83)$ & 49 \\
\hline 4 & $\mathrm{R}=4-\mathrm{C}_{6} \mathrm{H}_{4} \mathrm{~F}$ & 1 & $98(76)$ & 98 \\
\hline 5 & $\mathrm{R}=3-\mathrm{C}_{6} \mathrm{H}_{4} \mathrm{Cl}$ & 0.5 & $>99(69)$ & 200 \\
\hline 6 & $\mathrm{R}=2-\mathrm{C}_{6} \mathrm{H}_{4} \mathrm{Br}$ & 0.5 & $>99(87)$ & 200 \\
\hline 7 & $\mathrm{R}=4-\mathrm{C}_{6} \mathrm{H}_{4} \mathrm{Br}$ & 0.5 & $>99(76)$ & 200 \\
\hline 8 & $\mathrm{R}=3-\mathrm{C}_{6} \mathrm{H}_{4} \mathrm{NO}_{2}$ & 0.5 & $99(87)$ & 198 \\
\hline 9 & $\mathrm{R}=4-\mathrm{C}_{6} \mathrm{H}_{4} \mathrm{CO}_{2} \mathrm{Et}$ & 0.5 & $97(89)$ & 194 \\
\hline 10 & $\mathrm{R}=4-\mathrm{C}_{6} \mathrm{H}_{4} \mathrm{COMe}$ & 0.5 & $97(90)$ & 194 \\
\hline 11 & $\mathrm{R}=2-\mathrm{C}_{6} \mathrm{H}_{4} \mathrm{Me}$ & 7 & $87(73)$ & 12 \\
\hline 12 & $\mathrm{R}=3-\mathrm{C}_{6} \mathrm{H}_{4} \mathrm{OMe}$ & 3 & $97(85)$ & 32 \\
\hline 13 & $\mathrm{R}=4-\mathrm{C}_{6} \mathrm{H}_{4} \mathrm{OMe}$ & 3 & $98(79)$ & 33 \\
\hline 14 & $\mathrm{R}=4-\mathrm{C}_{6} \mathrm{H}_{4} \mathrm{NH}_{2}$ & 24 & $93(69)$ & 4 \\
\hline 15 & $\mathrm{R}=2$-Thienyl & 0.5 & $>99(75)$ & 200 \\
\hline 16 & $\mathrm{R}=3$-Furyl & 2 & $98(79)$ & 49 \\
\hline 17 & $\mathrm{R}=2-\mathrm{Py}$ rrolyl & 24 & $96(81)$ & 4 \\
\hline 18 & $\mathrm{R}={ }^{\mathrm{n}} \mathrm{Pr}$ & 1 & $>99(93)$ & 200 \\
\hline 19 & $\mathrm{R}={ }^{\mathrm{n} P e n t}$ & 4 & $99(85)$ & 25 \\
\hline 20 & $\mathrm{R}=\mathrm{Cy}$ & 2.5 & > $99(89)$ & 40 \\
\hline 21 & $\mathrm{R}=\mathrm{CH}_{2} \mathrm{Cl}$ & 0.5 & > $99(74)$ & 200 \\
\hline 22 & $\mathrm{R}=\mathrm{CH}_{2}$-2-thienyl & 1 & $>99(96)$ & 100 \\
\hline 23 & $\mathrm{R}=\mathrm{CH}_{2} \mathrm{CH}_{2} \mathrm{OPh}$ & 0.5 & $99(76)$ & 198 \\
\hline $24^{[d]}$ & $\mathrm{R}=\mathrm{CH}_{2} \mathrm{C}(=\mathrm{O}) \mathrm{Ph}$ & 1 & $>99(85)$ & 100 \\
\hline $25^{[d]}$ & $\mathrm{R}=\mathrm{CH}_{2} \mathrm{C}(=\mathrm{O})^{\mathrm{t}} \mathrm{Bu}$ & 1 & > $99(79)$ & 100 \\
\hline
\end{tabular}

[a] Reactions performed under argon atmosphere at $100 \stackrel{\circ}{\circ} \mathrm{C}$ using $1 \mathrm{mmol}$ of the corresponding nitrile $(0.33 \mathrm{M}$ in water). [b] Yields determined by GC (uncorrected GC areas). Isolated yields after appropriate workup are given in brackets. [c] Turnover frequencies ((mol product/mol Os)/time). [d] The NMR spectra of the $\beta$-ketoamide products showed the presence of a tautomeric mixture of the keto and enol forms in 1.6:1 (entry 24) and 2.3:1 ratio (entry 25). 
In addition, 5a proved to be also useful for the synthesis of diamides from dinitriles. As a representative example, fumaronitrile could be doubly hydrated under the standard reaction conditions, i.e. with $1 \mathrm{~mol} \%$ of $\mathbf{5 a}$ in pure water at 100 ${ }^{\circ} \mathrm{C}$, to generate selectively $(E)-\mathrm{H}_{2} \mathrm{NC}(=\mathrm{O}) \mathrm{CH}=\mathrm{CHC}(=\mathrm{O}) \mathrm{NH}_{2}$ in $93 \%$ GC yield after $2 \mathrm{~h}$ (70\% isolated yield after work-up). The synthetic utility of $\left[\mathrm{OsCl}_{2}\left(\eta^{6}\right.\right.$-p-cymene) $\left.\left\{\mathrm{PPh}_{2}\left(\mathrm{NMe}_{2}\right)\right\}\right]$ (5a) was further evidenced with the successful synthesis of the antiepileptic drug rufinamide $17,{ }^{[22]}$ which could be generated in $86 \%$ GC yield $(61 \%$ isolated yield) by hydration of the heterocyclic nitrile 4-cyano-1-(2,6-difluorobenzyl)-1H-1,2,3triazole 16 (Scheme 4). However, in this case a longer reaction time was needed $(24 \mathrm{~h})$ due to the presence of the coordinating triazole unit.

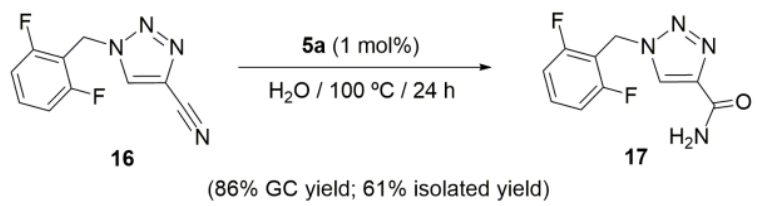

Scheme 4. Catalytic synthesis of rufinamide 17 employing complex $5 a$.

As commented above, the presence of the amino group in the $P$-donor ligand skeleton is key for the catalytic reaction to work efficiently, which in principle could be explained through the commonly proposed $\mathrm{H}$-bonding cooperative effect depicted in Figure 1. However, it is also known that amino-phosphanes, in both free state or coordinated to a metal fragment, are prone to undergo hydrolytic cleavage of the P-N bond. ${ }^{[23]}$ Starting from $\left[\mathrm{OsCl}_{2}\left(\eta^{6}\right.\right.$-p-cymene $\left.)\left\{\mathrm{PPh}_{2}\left(\mathrm{NMe}_{2}\right)\right\}\right] \quad$ (5a) such a hydrolysis process would lead to the formation of the phosphinous acid derivative $\left[\mathrm{OsCl}_{2}\left(\eta^{6}\right.\right.$-p-cymene $\left.)\left\{\mathrm{PPh}_{2}(\mathrm{OH})\right\}\right]$ (18), a compound previously described by us and also active in the hydration of nitriles. ${ }^{[5 b]}$ In line with this, it was very striking to find that, under identical reaction conditions, the activities of $5 a$ and $\mathbf{1 8}$ were very similar. Thus, for the model benzonitrile, 50 and $99 \%$ GC yields of benzamide were reached after 1 and $3 \mathrm{~h}$ of heating at $100 \stackrel{\circ}{ } \mathrm{C}$, respectively, in the presence of $1 \mathrm{~mol} \%$ of 18 (to be compared with the data given for $5 a$ in entry 13 of Table 2 ). This fact prompted us to examine by ${ }^{31} \mathrm{P}\left\{{ }^{1} \mathrm{H}\right\}$ NMR spectroscopy the species present in aqueous solution after the heating of both compounds at the working temperature of the catalytic experiments. To this end, two NMR tubes containing the complexes dissolved in $\mathrm{D}_{2} \mathrm{O}$ were heated at $100{ }^{\circ} \mathrm{C}$ in an oil bath for $3 \mathrm{~h}$. The ${ }^{31} \mathrm{P}\left\{{ }^{1} \mathrm{H}\right\}$ NMR spectra subsequently recorded were very clarifying. In both cases, a major singlet signal at $\delta \mathrm{p} 84 \mathrm{ppm}$ was observed. ${ }^{[24]}$ Almost identical ${ }^{31} \mathrm{P}\left\{{ }^{1} \mathrm{H}\right\}$ NMR spectra were also obtained when the same heating process of $5 a$ and 18 in $\mathrm{D}_{2} \mathrm{O}$ was performed in the presence of pentafluorobenzonitrile, with the singlet signal at $84 \mathrm{ppm}$ being again the major one (copies of all these spectra have been included in the Supporting Information). All this facts strongly support that the amino-phosphane $\mathrm{PPh}_{2}\left(\mathrm{NMe}_{2}\right)$ is transformed under the catalytic conditions into the phosphinous acid $\mathrm{PPh}_{2} \mathrm{OH}$, operating in this way the catalytic cycle depicted in Scheme 1 in nitrile hydration reactions reported in this work.

\section{Conclusions}

In summary, different half-sandwich Os(II) derivatives with amino-phosphane ligands have been synthesized, i.e. compounds $\left[\mathrm{OsCl}_{2}\left(\eta^{6}\right.\right.$-p-cymene $\left.)\left\{\mathrm{PPh}_{3-\mathrm{n}}\left(\mathrm{NR}_{2}\right)_{\mathrm{n}}\right\}\right]$ ( $\mathrm{n}=1-3, \mathrm{R}=$ $\mathrm{Me}, \mathrm{Ph}$ ), and evaluated as potential catalysts for nitrile hydration. Among them, compound $\left[\mathrm{OsCl}_{2}\left(\eta^{6}\right.\right.$-p-cymene $\left.)\left\{\mathrm{PPh}_{2}\left(\mathrm{NMe}_{2}\right)\right\}\right]$ resulted to be the most effective in catalysis. Thus, using only 1 mol\% of this complex and performing the reactions in pure water, a large variety of organonitriles could be selectively converted into the corresponding primary amides in high yields and short times, without the requirement of any acidic or basic additive. The nitrile hydration process was compatible with the presence of common functional groups on the substrates, and, more importantly, the performance shown by $\left[\mathrm{OsCl}_{2}\left(\eta^{6}-p\right.\right.$ cymene) $\left.\left\{\mathrm{PPh}_{2}\left(\mathrm{NMe}_{2}\right)\right\}\right]$ surpassed those of related $\mathrm{Ru}(\mathrm{II}), \mathrm{Ru}(\mathrm{IV})$, $\mathrm{Rh}(\mathrm{I})$ and $\mathrm{Pt}(\mathrm{II})$ species featuring the same amino-phosphane ligand $\mathrm{PPh}_{2}\left(\mathrm{NMe}_{2}\right)$, thus giving additional evidence of the enormous potential of osmium in this catalytic transformation. ${ }^{[5 b]}$ On the other hand, the observations made in this work suggest a rethinking of the role really played by the amino-phosphane ligands in the metal-catalyzed hydration of nitriles (precursors of phosphinous acids instead of simple $\mathrm{H}$-bond acceptors).

\section{Supporting Information Summary}

General information, experimental procedures and copies of the NMR spectra of all compounds are provided in the Supporting Information.

\section{Acknowledgements}

This work was supported by Spanish MINECO (project CTQ2016-75986-P) and the Government of the Principality of Asturias (project GRUPIN14-006). R. G.-F. thanks the University of Oviedo for a PhD scholarship.

Keywords: Amides • Amino-phosphanes $•$ Homogeneous catalysis $\cdot$ Nitrile hydration $\cdot$ Osmium

[1] See, for example: a) E. Valeur, M. Bradley, Chem. Soc. Rev. 2009, 38 606-631; b) V. R. Pattabiraman, J. W. Bode, Nature 2011, 480, 471479; c) C. L. Allen, J. M. J. Williams, Chem. Soc. Rev. 2011, 40, 34053415; d) S. Roy, S. Roy, G. W. Gribble, Tetrahedron 2012, 68, 98679923; e) J. W. Bode, Top. Organomet. Chem. 2013, 44, 13-34; f) P. Crochet, V. Cadierno, Chem. Commun. 2015, 51, 2495-2505; g) R. M. de Figueiredo, J.-S. Suppo, J.-M. Campagne, Chem. Rev. 2016, 116, 12029-12122.

[2] For reviews covering this topic, see: a) A. W. Parkins, Platinum Met. Rev. 1996, 40, 169-174; b) V. Y. Kukushkin, A. J. L. Pombeiro, Chem. Rev. 2002, 102, 1771-1802; c) V. Y. Kukushkin, A. J. L. Pombeiro, Inorg. Chim. Acta 2005, 358, 1-21; d) T. J. Ahmed, S. M. M. Knapp, D. R. Tyler, Coord. Chem. Rev. 2011, 255, 949-974; e) R. García-Álvarez, P. Crochet, V. Cadierno, Green Chem. 2013, 15, 46-66; f) E. L. Dows, D. R. Tyler, Coord. Chem. Rev. 2014, 280, 28-37. 
[3] a) T. Oshiki, H. Yamashita, K. Sawada, M. Utsunomiya, K. Takahashi, K. Takai, Organometallics 2005, 24, 6287-6290; b) T. Šmejkal, B. Breit, Organometallics 2007, 26, 2461-2464; c) V. Cadierno, J. Francos, V. Cadierno, Chem. Eur. J. 2008, 14, 6601-6605; d) R. García-Álvarez, J. Díez, P. Crochet, V. Cadierno, Organometallics 2010, 29, 3955-3965; e) V. Cadierno, J. Díez, J. Francos, J. Gimeno, Chem. Eur. J. 2010, 16 9808-9817; f) R. García-Álvarez, J. Francos, P. Crochet, V. Cadierno, Tetrahedron Lett. 2011, 52, 4218-4220; g) M. Muranaka, I. Hyodo, W Okumura, T. Oshiki, Catal. Today 2011, 164, 552-555; h) R. GarcíaÁlvarez, J. Díez, P. Crochet, V. Cadierno, Organometallics 2011, 30 5442-5451; i) S. M. M. Knapp, T. J. Sherbow, J. J. Juliette, D. R. Tyler Organometallics 2012, 31, 2941-2944; j) P. Daw, A. Sinha, S. M. W Rahaman, S. Dinda, J. K. Bera, Organometallics 2012, 31, 3790-3797; k) R. García-Álvarez, A. E. Díaz-Álvarez, J. Borge, P. Crochet, V. Cadierno, Organometallics 2012, 31, 6482-6490; I) R. García-Álvarez, S. E. García-Garrido, J. Díez, P. Crochet, V. Cadierno, Eur. J. Inorg Chem. 2012, 4218-4230; m) W.-C. Lee, J. M. Sears, R. A. Enow, K. Eads, D. A. Krogstad, B. J. Frost, Inorg. Chem. 2013, 52, 1737-1746; n) S. M. M. Knapp, T. J. Sherbow, R. B. Yelle, L. N. Zakharov, J. J. Juliette, D. R. Tyler, Organometallics 2013, 32, 824-834; o) R. GarcíaÁlvarez, M. Zablocka, P. Crochet, C. Duhayon, J.-P. Majoral, V. Cadierno, Green Chem. 2013, 15, 2447-2456; p) R. García-Álvarez, A E. Díaz-Álvarez, P. Crochet, V. Cadierno, RSC Adv. 2013, 3, 58895894; q) E. Tomás-Mendivil, R. García-Álvarez, C. Vidal, P. Crochet, V. Cadierno, ACS Catal. 2014, 4, 1901-1910; r) K. Singh, A. Sarbajna, I. Dutta, P. Pandey, J. K. Bera, Chem. Eur. J. 2017, 23, 7761-7771; s) M. K. Rong, K. van Duin, T. van Dijk, J. J. M. de Pater, B.-J. Deelman, M. Nieger, A. W. Ehlers, J. C. Slootweg, K. Lammertsma, Organometallics 2017, 36, 1079-1090.

[4] See, for example: a) T. Ghaffar, A. W. Parkins, Tetrahedron Lett. 1995 , 36, 8657-8660; b) T. Ghaffar, A. W. Parkins, J. Mol. Catal. A: Chem. 2000, 160, 249-261; c) S. M. M. Knapp, T. J. Sherbow, R. B. Yelle, J. J. Juliette, D. R. Tyler, Organometallics 2013, 32, 3744-3752; d) S. M. M. Knapp, T. J. Sherbow, T. J. Ahmed, I. Thiel, L. N. Zakharov, J. J. Juliette, D. R. Tyler, J. Inorg. Organomet. Polym. 2014, 24, 145-156; e) A. Mukherjee, R.-S. Liu, Org. Lett. 2011, 13, 660-663; f) T. Oshiki, M. Muranaka, PCT Int. Appl. WO 2012/017966; g) E. Tomás-Mendivil, L. Menéndez-Rodríguez, J. Francos, P. Crochet, V. Cadierno, RSC Adv. 2014, 4, 63466-63474; h) E. Tomás-Mendivil, F. J. Suárez, J. Díez, V. Cadierno, Chem. Commun. 2014, 50, 9661-9664; i) H. Gulyás, I. Rivilla S. Curreli, Z. Freixa, P. W. N. M. van Leeuwen, Catal. Sci. Technol. 2015, 5, 3822-3828; j) E. Tomás-Mendivil, J. Francos, R. GonzálezFernández, P. J. González-Liste, J. Borge, V. Cadierno, Dalton Trans. 2016, 45, 13590-13603.

[5] a) E. Tomás-Mendivil, V. Cadierno, M. I. Menéndez, R. López, Chem. Eur. J. 2015, 21, 16874-16886; b) R. González-Fernández, P. Crochet, V. Cadierno, M. I. Menéndez, R. López, Chem. Eur. J. 2017, 23 , 15210-15221.

[6] We would like to emphasize at this point that ruthenium is one of the metals most commonly employed in the hydration of nitriles and that compounds of type $\left[\mathrm{RuCl}_{2}\left(\eta^{6}\right.\right.$-arene $\left.)\left(\mathrm{PR}_{2} \mathrm{OH}\right)\right]$ are among the most active (see references $4 \mathrm{c}, \mathrm{f}$ and $5 \mathrm{a}$ ). For a recent review covering the specific contribution of ruthenium to the catalytic hydration of nitriles, see: R. García-Álvarez, J. Francos, E. Tomás-Mendivil, P. Crochet, V. Cadierno, J. Organomet. Chem. 2014, 771, 93-104.

[7] See, for example: a) R. A. Sánchez-Delgado, M. Rosales, M. A. Esteruelas, L. A. Oro, J. Mol. Catal. A: Chem. 1995, 96, 231-243; b) G. Chelucci, S, Baldino, W. Baratta, Acc. Chem. Res. 2015, 48, 363-379 c) G. Chelucci, G. A. Pinna, G. Pinna, M. Solinas, B. Sechi, Chin. J. Catal. 2016, 37, 1824-1836; d) M. L. Buil, M. A. Esteruelas, M. P. Gay, M. Gómez-Gallego, A. I. Nicasio, E. Oñate, A. Santiago, M. A. Sierra, Organometallics 2018, 37, 603-617 and references cited therein.

[8] a) E. Cariati, C. Dragonetti, L. Manassero, D. Roberto, F. Tessore, E. Lucenti, J. Mol. Catal. A. Chem. 2003, 204-205, 279-285; b) I. N. Stepanenko, B. Cebrián-Losantos, V. B. Arion, A. A. Krokhin, A. A.
Nazarov, B. K. Keppler, Eur. J. Inorg. Chem. 2007, 400-411; c) S. M. Ashraf, W. Kandioller, M.-G. Mendoza-Ferri, A. A. Nazarov, C. G Hartinger, B. K. Keppler, Chem. Biodivers. 2008, 5, 2060-2066; d) M. L. Buil, V. Cadierno, M. A. Esteruelas, J. Gimeno, J. Herrero, S. Izquierdo, E. Oñate, Organometallics 2012, 31, 6861-6867.

[9] H. Schumann, J. Organomet. Chem. 1986, 299, 169-178.

[10] Mononuclear Os(II) complexes with amino-phosphanes are relatively rare, the examples reported in the literature involving mainly $N$-pyrrolyl or $N$-pyrrolidinyl phosphanes: a) J. Huang, S. Serron, S. P. Nolan, Organometallics 1998, 17, 4004-4008; b) C. E. F. Rickard, W. R. Roper, S. D. Woodgate, L. J. Wright, J. Organomet. Chem. 2002, 643-644, 168-173; c) G. R. Clark, G.-L. Lu, C. E. F. Rickard, W. R. Roper, L. J. Wright, J. Organomet. Chem. 2005, 690, 3309-3320.

[11] H. Werner, K. Zenkert, J. Organomet. Chem. 1988, 345, 151-166.

[12] For selected examples involving rhodium, see references $3 \mathrm{j}, \mathrm{q}$ and: a) $M$. C. K.-B. Djoman, A. N. Ajjou, Tetrahedron Lett. 2000, 41, 4845-4849; b) A. Goto, K. Endo, S. Saito, Angew. Chem. Int. Ed. 2008, 47, 36073609; Angew. Chem. 2008, 120, 3663-3665; c) A. Goto, H. Naka, R. Noyori, S. Saito, Chem. Asian J. 2011, 6, 1740-1743.

[13] For selected examples involving platinum, see references $4 a, b, d, i$ and: a) V. Cadierno, Appl. Sci. 2015, 5, 380-401 and references cited therein; b) D. L. Dows, D. R. Tyler, J. Inorg. Organomet. Polym. 2015, $25,73-80$

[14] Our group previously demonstrated that the bis(allyl)-ruthenium(IV) fragment $\left[\mathrm{RuCl}_{2}\left(\eta^{3}: \eta^{3}-\mathrm{C}_{10} \mathrm{H}_{16}\right)\right]$ offers an excellent platform to design highly active nitrile hydration catalysts. See, references $3 e, 4 h, j$ and: $P$. J. González-Liste, V. Cadierno, S. E. García-Garrido, ACS Sustainable Chem. Eng. 2015, 3, 3004-3011.

[15] See, for example: a) T. Behling, G. S. Girolami, G. Wilkinson, R. G Somerville, M. B. Hursthouse, J. Chem. Soc., Dalton Trans. 1984, 877881 ; b) C. L. Gross, G. S. Girolami, Organometallics 1996, 15, 53595367.

[16] For reviews covering the coordination chemistry and applications of dimer $\left[\left\{\mathrm{RuCl}(\mu-\mathrm{Cl})\left(\eta^{3}: \eta^{3}-\mathrm{C}_{10} \mathrm{H}_{16}\right)\right\}_{2}\right]$ (11), see: a) V. Cadierno, P. Crochet, S. E. García-Garrido, J. Gimeno, Curr. Org. Chem. 2006, 10, 165-183; b) C. Bruneau, M. Achard, Coord. Chem. Rev. 2012, 256, 525-536; c) J. Francos, S. E. García-Garrido, J. García-Álvarez, P. Crochet, J. Gimeno, V. Cadierno, Inorg. Chim. Acta 2017, 455, 398-414.

[17] The catalytic behaviour of $\left[\mathrm{RhCl}(\mathrm{COD})\left\{\mathrm{PPh}_{2}\left(\mathrm{NMe}_{2}\right)\right\}\right]$ (13) in the hydration of benzonitrile in pure water had been previously reported by us (ref. 3q). In this previous work, employing a higher metal loading ( 5 mol\%), and extending the heating at $100{ }^{\circ} \mathrm{C}$ to $7 \mathrm{~h}$, a $54 \%$ yield of benzamide could be reached.

[18] See, for example: a) M. S. Balakrishna, S. S. Krishnamurthy, R. Murugavel, M. Nethaji, I. I. Mathews, J. Chem. Soc., Dalton Trans. 1993, 477-482; b) A. D. Burrows, M. F. Mahon, M. T. Palmer, J. Chem. Soc., Dalton Trans. 2000, 3615-3619; c) A. D. Burrows, M. F. Mahon, M. Varrone, Inorg. Chim. Acta 2003, 350, 152-162; d) M. S. Balakrishna, D. Suresh, P. P. George, J. T. Mague, Polyhedron 2006, 25, 3215-3221.

[19] Just for comparison, the ${ }^{1} \mathrm{JPt}_{\mathrm{Pt}, \mathrm{P}}$ coupling constants in the cis and trans isomers of the closely related complex $\left[\mathrm{PtCl}_{2}\left\{\mathrm{PPh}_{2}\left(\mathrm{NEt}_{2}\right)\right\}_{2}\right]$ are 3994 and $2926 \mathrm{~Hz}$, respectively: P. W. Dyer, J. Fawcett, M. J. Hanton, R. D. W. Kemmitt, R. Padda, N. Singh, Dalton Trans. 2003, 104-113.

[20] R. González-Fernández, P. J. González-Liste, J. Borge, P. Crochet, V. Cadierno, Catal. Sci. Technol. 2016, 6, $4398-4409$ and references cited therein.

[21] The osmium catalyst remained mostly dissolved and, after separation of the crystallized amide, the aqueous solution maintained intact its catalytic activity. This was evidenced in the case of pentafluorobenzonitrile, for which no differences in activities were found between the first and second use (full conversion by GC after $30 \mathrm{~min}$.).

[22] See, for example: a) S. Hakimian, A. Cheng-Hakimian, G. D. Anderson, J. W. Miller, Expert Opin. Pharmacother. 2007, 8, 1931-1940; b) J. L. Herranz, Rev. Neurol. 2008, 47, 369-373; c) C. S. Wisniewski, Ann. Pharmacother. 2010, 44, 658-667. 
[23] For a review on the synthesis and reactivity of amino-phosphanes, see: J. Gopalakrishnan, Appl. Organomet. Chem. 2009, 23, 291-318.

[24] Taking into account the ${ }^{31} \mathrm{P}\left\{{ }^{1} \mathrm{H}\right\}$ NMR shifts of complexes $\left[\mathrm{OsCl}_{2}\left(\eta^{6}-p\right.\right.$ cymene) $\left.\left\{\mathrm{PPh}_{2}\left(\mathrm{NMe}_{2}\right)\right\}\right]$ (5a) and $\left[\mathrm{OsCl}_{2}\left(\eta^{6}\right.\right.$-p-cymene) $\left.\left\{\mathrm{PPh}_{2}(\mathrm{OH})\right\}\right]$ (18) ( $\delta \mathrm{p} 30$ and $64 \mathrm{ppm}$, respectively), the singlet resonance observed at 84 $\mathrm{ppm}$ (slightly deshielded with respect to that of 18) could correspond to the cationic aquo-complex $\left[\mathrm{OsCl}\left(\mathrm{D}_{2} \mathrm{O}\right)\left(\eta^{6}\right.\right.$-p-cymene $\left.)\left\{\mathrm{PPh}_{2}(\mathrm{OD})\right\}\right][\mathrm{Cl}]$
The presence of four doublet resonances of equal intensity for the aromatic protons of the coordinated $p$-cymene ring in the corresponding ${ }^{1} \mathrm{H}$ NMR spectra would also be in accord with the formation of this cationic species. 


\section{Entry for the Table of Contents}

\section{FULL PAPER}

Half-sandwich Os(II) complexes of general composition $\left[\mathrm{OsCl}_{2}\left(\eta^{6}-p-\right.\right.$ cymene) $\left.\left\{\mathrm{PPh}_{3-\mathrm{n}}\left(\mathrm{NR}_{2}\right)_{\mathrm{n}}\right\}\right]$ ( $\mathrm{n}=1-3, \mathrm{R}$ $=\mathrm{Me}, \mathrm{Et}$ ) have been synthesized and successfully employed as precatalysts for the selective hydration of nitriles into primary amides in pure water.

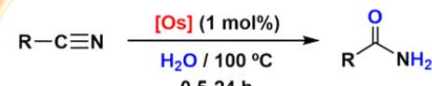

$$
\begin{aligned}
& \text { 0.5-24 h } \\
& 86-99 \% \text { GC yield } \\
& \text { (TOF up to } 200 \mathrm{~h}^{-1} \text { ) }
\end{aligned}
$$

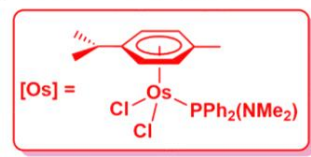

Nitrile hydration by osmium

Rebeca González-Fernández,

Pascale Crochet, ${ }^{*}$ Victorio Cadierno*

Page No. - Page No.

Cymene-Osmium(II) Complexes with Amino-Phosphane Ligands as

Precatalysts for Nitrile Hydration

Reactions 